Jan L. Bednarczyk*

\title{
POLITYKA PIENIĘŻNA EUROPEJSKIEGO BANKU CENTRALNEGO A ZAGROŻENIE DEFLACJĄ W UNII EUROPEJSKIEJ
}

\section{Wprowadzenie}

Strefa euro należy do najwolniej rozwijających się obszarów globalnej gospodarki. Stagnacji wzrostu gospodarczego towarzyszy jednocześnie niska inflacja, która od grudnia 2014 r. przeszła w fazę deflacji. Poprzedni epizod deflacyjny w strefie euro miał miejsce w okresie maj-październik 2009 r. i nałożył się w czasie na najgłębsze załamanie koniunktury, jakie dotychczas przeszły kraje tej strefy (-4,4\% w 2009 r.). Pojawiły się więc obawy, że krajom członkowskim może grozić powtórzenie się negatywnego scenariusza równoczesnego spadku poziomu cen i załamania wzrostu gospodarczego, co z kolei pobudziło dyskusję na temat adekwatności polityki pieniężnej Europejskiego Banku Centralnego (EBC) do zaistniałej sytuacji makroekonomicznej.

Pytanie o adekwatność działań EBC jest uzasadnione ze względu na nałożony na Bank obowiązek utrzymywania stopy inflacji na poziomie zbliżonym do $2 \%$, co siłą rzeczy zawęża też skalę działań, jakie może on podjąć, aby gospodarka w większym zakresie mogła realizować również inne ważne cele (na przykład przyspieszenie wzrostu gospodarczego). Poza tym w polityce EBC często zderzają się ze sobą sprzeczne interesy krajów członkowskich, co powoduje, że nie zawsze nadąża ona za potrzebami tych państw jako całości. Cechuje ją duża ostrożność w inicjowaniu i przeprowadzaniu zmian, co zwłaszcza w sytuacjach kryzysowych może generować niepewność i brak wiary w długookresowe perspektywy wzrostu.

W miarę jak wskaźniki inflacji w strefie euro zaczęły odchylać się w dół od założonego celu (od stycznia 2013 r.), władze EBC zmieniały stopniowo nastawienie w realizowanej polityce ze stricte antyinflacyjnego na bardziej prowzrostowe. Wprawdzie pewne działania w tym duchu podejmowano wcześniej, to jednak prowadzone były one zgodnie z przyjętą przez EBC logiką wykorzystywania rynkowych mechanizmów

* Politechnika Świętokrzyska, Wydział Zarządzania i Modelowania Komputerowego. 
stabilizacji systemu finansowego (zwłaszcza wykorzystywania funkcji banku centralnego jako pożyczkodawcy ostatniego szczebla) i okazały się w sumie mało skuteczne ${ }^{1}$. W ich wyniku doszło do fragmentacji (financial fragmentation) rynków finansowych krajów strefy euro, której Bank nie był w stanie do końca przezwyciężyć. Charakter działań podjętych w 2013, a następnie w 2014 r. był o tyle odmienny, że zaczęto wykorzystywać doświadczenia innych banków centralnych (głównie Systemu Rezerwy Federalnej, Banku Japonii oraz Banku Anglii) w przezwyciężaniu kryzysu i wspieraniu wzrostu gospodarczego, łącznie z wdrażaniem sprawdzonych tam metod określania średnioterminowych celów polityki pieniężnej oraz narzędzi jej urzeczywistniania (luzowanie ilościowe i jakościowe).

Podstawową przesłanką wprowadzonych przez EBC zmian jest niewątpliwie próba powtórzenia sukcesu, jakim okazało się użycie przez czołowe banki centralne na niespotykaną dotychczas skalę niestandardowych metod sterowania gospodarką (redukcja w pobliże zera oficjalnych stóp procentowych, luzowanie ilościowe i jakościowe, ogłaszanie zamiarów co do przyszłego poziomu parametrów ekonomicznych - stopy procentowej, wzrostu gospodarczego, stopy bezrobocia itp.). Otwarte pozostaje jednak pytanie, czy skala, termin i sposób wprowadzania zmian w polityce EBC dają szanse na to, że ich skuteczność będzie podobna jak w innych krajach. Celem niniejszego opracowania jest próba uzasadnienia tezy, że obecny zakres wdrażania niestandardowych działań w polityce EBC może okazać się niewystarczający, czego skutkiem będzie nasilanie się presji deflacyjnej z negatywnymi konsekwencjami dla perspektyw wzrostu gospodarczego.

\section{Nowy typ niestandardowych działań w polityce EBC}

Za początek wdrażania w polityce EBC działań wzorowanych bezpośrednio na doświadczeniach czołowych banków centralnych (forward guidance) można przyjąć decyzję Rady Prezesów EBC z 4 lipca 2013 r., w której postanowiono utrzymać sprzyjający ożywieniu (accomodative) charakter polityki pieniężnej „przez tak długi okres czasu przez jaki to będzie konieczne” oraz opinię tego gremium, zakładającą, że kluczowe stopy procentowe EBC pozostaną na dotychczasowym lub niższym poziomie przez „dłuższy okres czasu” ${ }^{2}$ W istocie główna stopa procentowa

1 Zob. J.L. Bednarczyk, Polityka pieniężna EBC a perspektywy ożywienia w strefie euro, w: Polska w Unii Europejskiej i globalnej gospodarce, red. M. Gorynia, S. Rudolf, PTE, Warszawa 2010, s. 290-294.

2 Zob. M. Draghi, V. Constâncio, Introductory statement to the press conference (with Q@A), Frankfurt am Main, 4 July 2013, www.ebc.europa.eu, dostęp 15.03.2015. 
operacji refinansowych EBC ( $f$ ix rate) została zredukowana w okresie maj 2013-wrzesień 2014, „w trzech ruchach” z 0,5 do 0,05\%, oprocentowanie kredytów overnight banku centralnego dla banków komercyjnych (marginal lending facility) z 1,0 do $0,3 \%$ oraz oprocentowanie depozytów banków komercyjnych w banku centralnym (doposit rate) z 0,0 do $-0,2^{3}$. Równolegle do redukcji stóp procentowych uruchomiono programy zakupu na dużą skalę aktywów (Large Scale Asset Purchase, LSAP), których bezpośrednim skutkiem miało być zapewnienie gospodarce państw strefy euro płynności, a skutkiem pośrednim ożywienie popytu i koniunktury. Pierwsze programy masowych zakupów aktywów zostały uruchomione w 2014 r. (Asset Backed Securities and Covered Bond Purchase Programme - ABSPP, CBPP a także Targeted Long-term Refinancing Operations, TLTRO), a ostatni w roku 2015 (Expanded Asset Purchase Programme - APP $)^{4}$. Programy zakupów długu prywatnego zabezpieczonego na aktywach (ABSPP i CBPP) miały służyć nie tylko poprawie płynności banków komercyjnych, ale również przyczynić się do obniżki rynkowych stóp procentowych oraz ożywienia rynku kredytów dla przedsiębiorstw. Dodatkowym wsparciem dla banków rozwijających dynamicznie działalność kredytową miał być program TLTRO. Wkrótce po uruchomieniu obydwu programów okazało się jednak, że są one wykorzystywane w niewystarczającym stopniu (zwłaszcza TLTRO), co groziło załamaniem się całej koncepcji wsparcia płynnościowego sektora bankowego dla ożywienia popytu.

W tej sytuacji EBC został niejako zmuszony do podjęcia bardziej radykalnych działań. Zaznacza się przy tym wyraźne podobieństwo pomiędzy środkami podjętymi przez EBC a ogólnymi zasadami polityki pieniężnej realizowanej z użyciem luzowania ilościowego i jakościowego oraz forward guidance. Rada Prezesów na posiedzeniu 22 stycznia 2015 r. zdecydowała o zainicjowaniu rozszerzonego programu zakupów aktywów (Asset Purchase Programme, APP), dołączając do skupowanych dotychczas zobowiązań emitowanych przez instytucje prywatne, również skup na rynku wtórnym, posiadających właściwy rating papierów wartościowych nominowanych w euro i emitowanych przez rządy, agencje oraz instytucje europejskie ${ }^{5}$. W ramach rozszerzonego programu przewidziano miesięczne zakupy zarówno papierów prywatnych jak i publicznych na kwotę do 60 mld EUR w okresie co najmniej do września 2016 r. Wyrażono przy tym intencję kontynuowania skupu papierów dopóty, dopóki

3 Key ECB interest rates, ECB, www.ebc.europa.eu, dostęp 15.03.2015.

4 Chronology of Monetary Policy Measures of the Eurosystem, "ECB Monthly Bulletin" 2014, No. 1, Annexes, s. I-III.

5 The Governing Council 's Expanded Asset Purchase Programme, "ECB Economic Bulletin" 2015, No. 1, Box 1, s. 15-18. 
tempo wzrostu cen nie zacznie osiągać wartości spójnych z osiągnięciem w średnim okresie celu inflacyjnego EBC, tj. stopy inflacji zbliżonej do $2 \%{ }^{6}$.

Bezpośrednim skutkiem decyzji EBC dotyczących skupu papierów wartościowych jest powiększanie się bilansu Banku, co z kolei przekłada się na wzrost bazy monetarnej, wielkość obiegu pieniężnego i wskaźniki inflacji. W dotychczasowej historii EBC daje się zauważyć dwa okresy znaczącego powiększenia się jego bilansu. Pierwszy rozpoczął się w okresie zaostrzania się kryzysu finansowego związanego z groźbą upadku Lehman Brothers i drugi w 2011 r., kiedy gospodarka krajów strefy euro zaczęła wyhamowywać wskutek wdrażanego zacieśniania fiskalnego. W rezultacie działań podjętych w celu zabezpieczenia sektora bankowego strefy euro przed „efektem zarażania” i dostarczenia bankom niezbędnej ilości gotówki, bilans EBC wykazał na koniec 2008 r. wartość ponad trzykrotnie wyższą od wartości z końca 2007 r. (odpowiednio: 383,9 mld i 126 mld EUR) 7 . Tak wydatne powiększenie bilansu było głównie skutkiem zaciągnięcia przez EBC krótkoterminowego kredytu w Systemie Rezerwy Federalnej, w kwocie 219,7 mld EUR, który posłużył do złagodzenia problemów firm i instytucji europejskich w zakresie regulowania zobowiązań nominowanych w USD. Podobny cel miała również pożyczka na kwotę 18,4 mld EUR zaciągnięta przez EBC w Narodowym Banku Szwajcarii ${ }^{8}$.

Drugi okres znaczącego powiększenia bilansu EBC przypada na lata 2011-2012. Państwa strefy euro weszły wówczas w fazę pogłębiającego się kryzysu zadłużenia publicznego (widocznego zwłaszcza w krajach tzw. grupy PIIGS), będącego skutkiem pomocy udzielanej przez państwa podmiotom sektora prywatnego. Polityka EBC dążyła do zachowania równowagi pomiędzy zacieśnieniem fiskalnym, jakie dokonywało się w większości krajów strefy euro a tworzeniem warunków do podtrzymania wygasającego ożywienia koniunktury, głównie poprzez dążenie do zapewnienia płynności sektora bankowego i udrożnienie mechanizmów obiegu pieniądza $\mathrm{w}$ gospodarce ( $\mathrm{w}$ tym również w sektorze bankowym), przy ograniczonej ingerencji w rynek rządowych papierów wartościowych i w rynek długu prywatnego ${ }^{9}$. U podstaw operacji EBC na rynku publicznych papierów wartościowych leżały przesłanki, które określały również charakter jego działalności jako pożyczkobiorcy ostatniego szczebla. Ponieważ sytuacja sektora bankowego była ciągle bardzo niepewna, groziła niewypłacalnością banków oraz pojawianiem się objawów paniki,

6 Zob. M. Draghi, Introductory statement to the plenary debate of the European Parliament on the EBC's Annual Report 2013, Brussel, 25 February 2015.

7 Raport roczny 2007, EBC, Frankfurt am Main 2008, s.109; Raport roczny 2008, EBC, Frankfurt am Main 2009, s. 236-237.

8 Raport roczny 2007, op.cit., s. 109.

9 Zob. B.W. Fawley, Ch.J. Neely, Four Stories of Quantitative Easing, "Federal Reserve Bank of St. Louis Review", January/February 2013, s. 71, 74, 75, 81. 
starano się monitorować i zabezpieczać płynność banków komercyjnych, funkcjonujących na najbardziej zagrożonych rynkach (liquidity targeting), a z drugiej strony nie dopuścić do tego, aby skutkiem podejmowanych działań przeciwkryzysowych stało się nadmierne zwiększenie obiegu pieniężnego, co z kolei mogłoby się przełożyć na wzrost cen ${ }^{10}$.

Głównymi narzędziami kształtowania płynności systemu bankowego i gospodarki były: 1) długoterminowe operacje refinansowe z horyzontem 6 miesięcy, 1 rok i 3 lata (Long-term Refinancing Operations, LTRO), 2) program skupu przez EBC w okresie czerwiec 2009-październik 2012, prywatnych obligacji zabezpieczonych aktywami lub publicznymi papierami wartościowymi (Covered Bonds Purchase Programme, CBPP), 3) program zakupu od banków papierów wartościowych, stanowiących standardowe zabezpieczenie pożyczek zaciąganych w EBC (maj 2010-wrzesień 2012), 4) realizacja dwóch transz skupu na rynku wtórnym obligacji państw strefy euro z terminem zapadalności do 36 miesięcy (grudzień 2011), 5) zastąpienie zakończonego we wrześniu 2012 r. programu zakupu od banków papierów wartościowych (Securities Market Program) możliwością zakupu obligacji emitowanych przez rządy krajów członkowskich strefy euro, pod warunkiem wypełnienia przez nich wymagań określonych przez Europejski Instrument Stabilności Finansowej/Europejski Mechanizm Stabilności ${ }^{11}$.

W wyniku działań podejmowanych przez EBC w latach 2011-2012 bilans Banku wykazał na koniec 2011 r. wartość 230,9 mld EUR (wzrost o ponad 40\% w stosunku do roku 2010) i 207,3 mld EUR na koniec roku 2012 (wzrost o prawie 27\% w stosunku do roku 2010). Cechą charakterystyczną zmian sumy bilansowej EBC w latach 2011-2012 było dość szybkie tempo powrotu jej wielkości do stanu sprzed przyspieszonego wzrostu. Istotnie, na koniec 2013 r. wielkość sumy bilansowej EBC tylko o nieco ponad 38\% przewyższała jej poziom sprzed kryzysu finansowego, tj. z $2007 \mathrm{r}$. $(174,2 \text { mld EUR })^{12}$.

Pewnym paradoksem polityki EBC w 2011 r. było zainicjowanie i wdrożenie podwyżek stóp procentowych. Podstawowa stopa procentowa (fixed rate) została podniesiona 13 kwietnia z $1 \%$ do $1,25 \%$, a następnie 13 lipca do 1,5 . Powodem podwyżek było przekroczenie w grudniu $2010 \mathrm{r}$. i w kolejnych miesiącach poziomu $2 \%$ inflacji. Seria podwyżek okazała się mocnym sygnałem dla gospodarki strefy euro,

${ }^{10}$ Non-standard monetary policy measures: where do we stand?, Speech by Benoit Cœuré, Member of the Executive Board of the ECB, at the International Monetary Seminar Sovereign Risk, Bank Risk and Central Banking organised by the Banque de France, Paris, 10 July 2013, www.ecb.europa.eu, dostęp 15.03.2015.

${ }^{11}$ Chronology..., op.cit., s. I-III.

12 Wszystkie dane dotyczące wielkości bilansu EBC podawane są za: Raport roczny, EBC cz. 2. Ramy instytucjonalne, organizacja i roczne sprawozdanie, za lata 2008-2014. 
wskazującym, że EBC nie zrezygnuje ze ścisłego wypełniania swojego mandatu, nawet gdyby miało to oznaczać spowolnienie wzrostu gospodarczego ${ }^{13}$. Istotnie, gospodarka strefy euro wchodziła stopniowo w fazę recesji.

Podsumowując, EBC właściwie od wybuchu kryzysu podejmował działania, które w tzw. normalnych warunkach nie byłyby stosowane; mogły być jedynie wskazywane jako narzędzia jego potencjalnego oddziaływania na system bankowy. Jednak przez ponad pięć lat od wybuchu kryzysu głównym obszarem oddziaływania EBC pozostawało kształtowanie płynności sektora bankowego, co miało zapewnić sprawność jego działania, drożność kanałów oddziaływania na całą gospodarkę i w konsekwencji pobudzić wzrost gospodarczy. Dopiero w połowie 2013 r., wobec nieskuteczności tej polityki (wystąpienia tzw. drugiego dna i fragmentacji rynków finansowych), zdecydowano się podjąć działania odpowiadające istocie luzowania ilościowego i jakościowego, a także pełniej i bardziej precyzyjnie informować rynki o celach oraz kierunkach polityki EBC (forward guidance). Ale nawet po zmianie formy komunikacji EBC z rynkami finansowymi, Bank wykazał duży konserwatyzm we wdrażaniu nowego podejścia, dozując środki i rozkładając w czasie ich implementację. Jednocześnie akcentował nadrzędność utrzymania inflacji na poziomie zbliżonym do $2 \%$, co z pewnością nie może pozostać obojętne dla oceny skali przyszłego ożywienia koniunktury dokonywanej przez podmioty gospodarcze.

\section{Mechanizmy transmisyjne i ich sprawność}

Aby móc ocenić szanse polityki EBC na poprawę perspektyw wzrostu gospodarczego w strefie euro, należy przyjrzeć się mechanizmom transmisyjnym wpływu polityki skupu papierów wartościowych na realną gospodarkę, tak jak je widzą władze $\mathrm{EBC}^{14}$. Wymienia się trzy kanały tego oddziaływania. Pierwszy z nich wiąże się $\mathrm{z}$ bezpośrednim wpływem zakupu papierów wartościowych na ich ceny (rynkowe stopy przychodu), płynność instytucji sprzedających oraz zdolność tych instytucji (głównie banków) do udzielania kredytów. Jego skutkiem jest zatem wzrost podaży kredytów oraz spadek ich oprocentowania. Podobny efekt powinny wywierać również dostosowania portfelowe (drugi mechanizm transmisyjny). Zakupy określonych

${ }_{13}$ J.-C. Trichet, The ECB 's response to the crisis. Speech at the WDR Europa-Forum, Berlin 26 May 2011, www. ecb.europa.eu, dostęp 15.03.2015.

${ }^{14} \mathrm{~V}$. Constâncio, Monetary policy challenges in the euro area, Speech at the Annual Conference of the Marshall Society, on The power of policy: solving problems and shaping the future, Cambridge 31 January 2015, www. ecb.europa.eu, dostęp 15.03.2015. 
aktywów i zmiany ich cen (a w konsekwencji napływ gotówki do sprzedających aktywa), powodują wzrost cen innych aktywów, takich jak obligacje, akcje, majątek trwały, aktywa zagraniczne itp. Wzrost cen aktywów podnosi wycenę majątku przedsiębiorstw i gospodarstw domowych, poprawiając też ich zdolność kredytową. Stwarza to warunki do ekspansji kredytu bankowego. Z kolei trzeci mechanizm wiąże się z działaniem tzw. efektu sygnalizacji, czyli zmian oczekiwań odnośnie do przyszłej inflacji oraz poziomu stóp procentowych $\mathrm{EBC}^{15}$. Jeśli w istocie zakupy papierów wartościowych skłonią uczestników rynku do przewidywania wzrostu inflacji wskutek wzrostu podaży pieniądza, to konsekwencją zmiany oczekiwań będzie spadek realnej stopy procentowej. Następstwem tego spadku będzie z kolei wzrost popytu na dobra konsumpcyjne oraz inwestycyjne, finansowane tańszym kredytem bankowym.

Siła oddziaływania dwóch pierwszych mechanizmów na podmioty sektora realnego zależy w istocie od sprawności mechanizmu trzeciego. Nawet jeśli bowiem zakupy papierów wartościowych stworzą podmiotom tego sektora warunki do zaciągania tańszych kredytów, to otwarty pozostaje problem, czy będą one skłonne zadłużać się, aby powiększać skalę prowadzonej działalności gospodarczej. Większa dostępność i niższy koszt kredytu bankowego mogą nie wystarczyć, jeśli podmioty sektora realnego nie będą dostrzegały perspektyw dynamicznego wzrostu sprzedaży, który zapewni im godziwy zwrot z poczynionych inwestycji. Pewną szansą dla strefy euro, znajdującej się pod presją deflacyjną, może być istotne pobudzenie oczekiwań inflacyjnych, gdyż przy relatywnie wysokim bezrobociu (stabilizującym wzrost płac), niskich cenach ropy naftowej i innych surowców, daje to podmiotom sfery realnej szanse na osiągnięcie wyższych przychodów ze sprzedaży i w konsekwencji (przy stabilnych kosztach) wyższych zysków. Problem tkwi jednak w skali oczekiwań inflacyjnych, które jest w stanie wygenerować w średnim okresie obecna polityka EBC. Uzasadnienia dla nasuwających się wątpliwości można poszukiwać, porównując kluczowe elementy polityki prowzrostowej wdrażanej przez EBC z polityką luzowania ilościowego wdrożoną przez System Rezerwy Federalnej, która zaowocowała szybkim wyprowadzeniem amerykańskiej gospodarki z kryzysu i utrzymywaniem tam jednej z najdłuższych faz ożywienia w ciągu ostatnich kilkudziesięciu lat.

System Rezerwy Federalnej rozpoczął zdecydowaną walkę z kryzysem finansowym już w 2007 r., a zatem wówczas, gdy pojawiły się jego pierwsze symptomy. W pierwszej kolejności uruchomione zostały w bezprecedensowo szybkim tempie i na rzadko spotykaną skalę standardowe narzędzia oddziaływania na system finansowy. Oprocentowanie funduszy federalnych, oficjalna stopa procentowa SRF, obniżone zostało w okresie od września 2007 do grudnia 2008 r. (a zatem w ciągu tylko

15 Ibidem. 
kilkunastu miesięcy) z 5,5\% do 0-0,25\%, czyli o 500 p.b. ${ }^{16}$. Jednocześnie, w celu obniżenia długoterminowych stóp procentowych oraz poprawy stanu płynności, rozpoczęto realizację na ogromną skalę programów zakupu papierów wartościowych zarówno podmiotów publicznych, jak i prywatnych oraz wspieranie akcji kredytowej banków. W sumie w latach 2008-2009 uruchomiono osiem wielkich projektów refinansowych ${ }^{17}$. Akcja wspierania ożywienia oraz podtrzymywania oczekiwań inflacyjnych (w celu uniknięcia deflacji) nabrała nowego wyrazu po ogłoszeniu w listopadzie 2008 r. nowego pakietu stymulacyjnego, nazwanego później Quantitative Easing 1. W ramach tego projektu SRF zadeklarował zakup od banków i instytucji finansowych papierów wartościowych zabezpieczonych hipotecznie na kwotę 600 mld USD. Druga edycja luzowania ilościowego ruszyła w listopadzie $2010 \mathrm{r}$. (zakup w okresie do połowy 2011 r. papierów skarbowych na dalsze 600 mld USD) i trzecia we wrześniu 2012 r. Ta ostatnia przewidywała realizację comiesięcznych zakupów papierów wartościowych, głównie zabezpieczonych hipotecznie, na kwotę $40 \mathrm{mld}$ USD, a od grudnia 2012 r. na kwotę 85 mld USD. Kwoty zakupów zostały zmniejszone w czerwcu 2013 r. do 65 mld USD i były ograniczane dalej, aż do całkowitego wygaszenia programu w październiku 2014 r. ${ }^{18}$. Niemniej, w trakcie trwania trzech transz programu, gospodarka amerykańska została systematycznie zasilona przez SRF gigantyczną kwotą kilku bilionów USD, co spowodowało m.in. prawie 4,5-krotne powiększenie się sumy bilansowej amerykańskiego banku centralnego w latach 2007-2013 oraz podobny wzrost dolarowej bazy monetarnej ${ }^{19}$. Pozwoliło to gospodarce amerykańskiej wejść już z początkiem 2009 r. w fazę długotrwałego (sustainable) ożywienia.

Mocnym wsparciem dla ożywienia gospodarki amerykańskiej było również ujawnianie przez SRF jego zamiarów co do przyszłego kształtowania się kluczowych parametrów gospodarczych, takich jak wysokość oficjalnej stopy procentowej, jak również co do priorytetów polityki pieniężnej (forward guidance). I tak, aby podtrzymać optymistyczne oczekiwania odnośnie do dalszego rozwoju koniunktury, SRF na posiedzeniu w grudniu 2012 r. wskazał wprost na rozwój gospodarczy i poprawę na rynku pracy jako główne priorytety polityki pieniężnej. Realizacji tych priorytetów miało służyć utrzymywanie oprocentowania funduszy federalnych w pobliżu

\footnotetext{
16 B. Bernanke, The Crisis and the Policy Response. Speech at the Stamp Lecture, London School of Economics, London, January 13, 2009. Board of Governors of the Federal Reserve System, www.federalreserve. gov, dostęp 15.03.2015.

17 Były to: TAF, TSLF, PDCF, AMLF (oraz MMIFF), CPFF, ABS CMBS-TALF, CMBS-TALF.

18 Annual Report 2008-2012, Board of Governors of the FRS, Washington D.C.; 100th Annual Report 2013, Board of Governors of the FRS, Washington D.C., May 2014, s. 20, 35.

${ }^{19} \mathrm{Na}$ koniec $2013 \mathrm{r}$. suma bilansowa SRF wynosiła nieco ponad 4 bln USD, podczas gdy na koniec $2007 \mathrm{r}$. niecałe $920 \mathrm{mln}$. Zob. Annual Report 2007, Board of Governors of the FRS, s. 324; Annual Report 2013, Board of Governors of the FRS, s. 334.
} 
zera tak długo, jak długo stopa bezrobocia będzie wyższa niż 6,5\%, pod warunkiem, że przewidywana na najbliższy rok - dwa lata inflacja nie przekroczy $2,5 \%{ }^{20}$. Stanowisko SRF z grudnia 2012 r. pokazało wyraźnie, jak daleka była ta instytucja od doktrynerskiego podchodzenia do stabilności cen. Jeśli względy wzrostu gospodarczego wymagały przejściowego podniesienia celu inflacyjnego (w tym wypadku z $2 \%$ do $2,5 \%$ ) zrobiono to, co mogło być dodatkowym mocnym sygnałem dla uczestników rynku, wskazującym na determinację władz we wspieraniu ożywienia. W wyniku mocnej i konsekwentnej stymulacji popytu w całym okresie pokryzysowym, gospodarka amerykańska uniknęła mocniejszej presji deflacyjnej, notując ujemny wskaźnik wzrostu cen tylko w roku 2009, kiedy wykazała również kilkuprocentowy spadek tempa wzrostu realnego PKB.

O ile środki podjęte przez SRF okazały się skuteczne w utrzymywaniu umiarkowanych oczekiwań inflacyjnych, co z kolei przekładało się na niższe realne długoterminowe stopy procentowe i wsparcie dla procesów ożywienia koniunktury, o tyle w wypadku EBC siła oddziaływania tego mechanizmu wydaje się być problematyczna. Jest wiele aspektów polityki EBC, które mogą spowodować jej niższą skuteczność:

- utrwalenie się (zakotwiczenie) w krajach strefy euro pesymistycznych oczekiwań co do perspektyw wzrostu gospodarczego, wskutek opieszałych, spóźnionych i zbyt słabych działań antykryzysowych Banku od 2007 r. Przypadek strefy euro może stać się powieleniem sytuacji, jaka wytworzyła się w Japonii na początku lat 90. XX w. i trwała do końca tej dekady, kiedy władze przez długi okres nie mogły poradzić sobie z presją deflacyjną, pomimo stosowania całego arsenału środków ekspansywnej polityki pieniężnej i budżetowej, które miały doprowadzić do jej złagodzenia,

- pomimo że gospodarka krajów strefy euro przeszła w okresie pokryzysowym przez podwójne załamanie, co spowodowało bezprecedensowy wzrost bezrobocia w krajach tej strefy, EBC nigdy nie określił w swojej polityce pożądanego w średnim okresie poziomu kluczowych wielkości realnych, takich np. jak pożądany poziom stopy bezrobocia czy tempo wzrostu gospodarczego, co mogłoby być dla podmiotów gospodarczych tej strefy rzeczywistym wyrazem determinacji władz w dążeniu do poprawy sytuacji gospodarczej i pomogło zmienić charakter ich oczekiwań zarówno co do wzrostu popytu, jak i przyszłej inflacji,

- cel inflacyjny traktowany był przez cały czas jako nadrzędny parametr polityki pieniężnej EBC, nawet po wdrożeniu w styczniu 2015 r. poszerzonego programu

${ }^{20}$ B.S. Bernanke, Semiannual Monetary Policy Report to the Congress. Before the Committee on Banking, Housing, and Urban Affairs, U.S. Senate, Washington, D.C. February 26, 2013, www.federalreserve.gov, dostęp 6.10.2013. 
zakupów papierów wartościowych. Rada Prezesów zapowiedziała, że zakupy te będą kontynuowane dopóty, dopóki stopa inflacji nie wróci do wartości zbliżonej do $2 \%$, jak to przewiduje mandat EBC. Rada nie poszła za przykładem amerykańskiego Federalnego Komitetu Otwartego Rynku (FOMC), ustalając np., że w czasie wdrażania nadzwyczajnych środków polityki wspierającej wzrost popytu w strefie euro, cel inflacyjny może być przejściowo przekraczany choćby o 0,5 p.p. Takie oficjalne zadeklarowanie elastyczności w kwestii celu inflacyjnego z pewnością wywarłoby pozytywny wpływ na oczekiwania inflacyjne i oczekiwany poziom realnych długoterminowych stóp procentowych. Tymczasem sztywne określenie docelowego, tolerowanego przez EBC poziomu inflacji, może oznaczać zbyt wąski margines dla wzrostu nominalnych dochodów, zniechęcając podmioty gospodarcze strefy euro do planowania większej skali produkcji, co z kolei może oznaczać wzmocnienie tendencji stagnacyjno-deflacyjnych,

- wdrożone przez EBC programy zakupów papierów wartościowych wywierały tylko przejściowy wpływ na bilans EBC oraz bazę monetarną w strefie euro. Porównując obydwie te wielkości na koniec 2007 i 2014 r. otrzymujemy odpowiednio wzrost o $47 \%$ i $50,3 \%{ }^{21}$. To bardzo niewiele $\mathrm{w}$ porównaniu z prawie pięciokrotnym wzrostem tych wielkości, w tym samym czasie, w Stanach Zjednoczonych. Tymczasem wielkość bazy monetarnej wpływa poprzez mnożnik na szersze agregaty pieniężne (M1, M2, M3), oczekiwania inflacyjne, a wreszcie na poziom inflacji i realne stopy procentowe.

Zatem, biorąc pod uwagę zakres oraz skalę wdrażania przez EBC niestandardowych działań w celu przezwyciężenia zagrożenia stagnacją wzrostu gospodarczego oraz deflacją w strefie euro, istotnie można mieć wątpliwości, czy są one adekwatne do skali problemu, który z ich użyciem Bank chce rozwiązać. Podjęcie zbyt słabych środków może spowodować, że siła oddziaływania mechanizmów transmisji ożywienia gospodarki strefy euro będzie niewystarczająca, a to z kolei może mieć trudne do przewidzenia skutki dla dalszego funkcjonowania strefy w jej dotychczasowym kształcie instytucjonalnym.

${ }^{21}$ Raport roczny, cz. II. Ramy instytucjonalne, organizacja i roczne sprawozdanie 2007, EBC; Raport roczny, cz. II. Ramy instytucjonalne, organizacja i roczne sprawozdanie 2014, EBC. 


\section{Podsumowanie}

Specyfika działania EBC jako banku centralnego polega na bardzo precyzyjnym określeniu jego mandatu, jakim jest utrzymywanie w krajach strefy euro inflacji na poziomie zbliżonym, lecz niższym od $2 \%$. Teoretyczne podstawy tak określonego mandatu osadzone są głęboko w dyskusjach, jakie toczyły się w kręgach teoretyków i praktyków gospodarczych w latach 80. poprzedniego stulecia, kiedy wydawało się, że zwalczanie presji inflacyjnej jest właściwie jedynym realnym problemem, z którym przyjdzie się mierzyć bankom centralnym w przyszłości. Tymczasem już w latach 90. doświadczenia gospodarki japońskiej pokazały, że równie realna i równie niebezpieczna dla rozwoju gospodarczego może być także presja deflacyjna. Przypadek japoński traktowany był jednak początkowo jako specyficzny i niewiele banków centralnych wyciągnęło $\mathrm{z}$ niego wnioski dla formułowania celów, zasad i wyboru narzędzi swojej polityki. Sytuacja ta uległa zmianie po kryzysie finansowym lat 20072008. Zagrożone rozwojem procesów deflacyjnych, czołowe banki centralne zaczęły na nieznaną dotychczas skalę wprowadzać niestandardowe metody oddziaływania na system finansowy, co zaowocowało podtrzymaniem oczekiwań inflacyjnych i ożywieniem gospodarki. EBC również modyfikował swoje podejście w kwestii doboru środków oddziaływania na gospodarkę strefy euro, jednak czynił to znacznie wolniej i w mniejszym zakresie niż czołowe banki świata, ciągle wskazując na ryzyko, jakie zmiana narzędzi i metod polityki pieniężnej mogłaby przedstawiać dla sprawowanego przez Bank mandatu. W konsekwencji strefa euro weszła w fazę znacznego spowolnienia wzrostu, czemu towarzyszy wysokie bezrobocie oraz narastanie presji deflacyjnej. Można wyrazić pogląd, że jeśli EBC nie odejdzie od polityki traktowania inflacji jako najważniejszego priorytetu na rzecz bardziej zrównoważonego podejścia do realizacji celów polityki gospodarczej (wzrost gospodarczy, zatrudnienie), to nawet wdrożone w styczniu 2015 r. elementy programu luzowania ilościowego mogą okazać się niewystarczające, aby pobudzić europejską gospodarkę i zatrzymać rozwój spirali deflacyjno-stagnacyjnej.

\section{Bibliografia}

100th Annual Report 2013, Board of Governors of the FRS, Washington D.C., May 2014. Annual Report 2008-2012, Board of Governors of the FRS, Washington D.C. 
Bednarczyk J.L., Polityka pieniężna EBC a perspektywy ożywienia $w$ strefie euro, w: Polska w Unii Europejskiej i globalnej gospodarce, red. M. Gorynia, S. Rudolf, PTE, Warszawa 2010.

Bernanke B., Semiannual Monetary Policy Report to the Congress. Before the Committee on Banking, Housing, and Urban Affairs, U.S. Senate, Washington, D.C. February 26, 2013, www.federalreserve.gov, dostęp 15.03.2015.

Bernanke B., The Crisis and the Policy Response. Speech at the Stamp Lecture, London School of Economics, London, January 13, 2009, Board of Governors of the FRS, www.federalreserve.gov, dostęp 15.03.2015.

Chronology of Monetary Policy Measures of the Eurosystem, "ECB Monthly Bulletin" January 2014.

Couré B., Non-standard monetary policy measures: where do we stand?, Speech at the International Monetary Seminar Sovereign Risk, Bank Risk and Central Banking organized by the Banque de France, Paris 10 July 2013, www.ecb.europa.eu, dostęp 15.03.2015.

Constâncio V., Monetary policy challenges in the euro area, Speech at the Annual Conference of the Marshall Society, The power of policy: solving problems and shaping the future", Cambridge 31 January 2015, www. ecb.europa.eu, dostęp 15.03.2015.

Draghi M., Constâncio V., Introductory statement to the press conference (with Q@A), Frankfurt am Main 4 July 2013, www.ebc.europa.eu, dostęp 15.03.2015.

Draghi M., Introductory statement to the plenary debate of the European Parliament on the EBC's Annual Report 2013, Brussel 25 February 2015.

Fawley B.W., Neely Ch.J., Four Stories of Quantitative Easing, Federal Reserve Bank of St. Louis Review, January/February 2013.

Key ECB interest rates, ECB, www.ebc.europa.eu, dostęp 15.03.2015.

Raport roczny za lata 2008-2014, cz. II. Ramy instytucjonalne, organizacja i roczne sprawozdanie, EBC.

Roczne sprawozdanie finansowe 2014, EBC, Frankfurt, luty 2015.

The Governing Council 's Expanded Asset Purchase Programme, "ECB Economic Bulletin", Issue $1 / 2015$.

Trichet J.-C., The ECB 's response to the crisis, Speech at the WDR Europa-Forum, Berlin 26 May 2011, www. ecb.europa.eu, dostęp 15.03.2015. 


\section{The European Central Bank's Monetary Policy and the Threat of Deflation in the European Union}

The aim of the paper is to assess whether the range of non-standard measures undertaken by the European Central Bank between 2014-2015 may turn out insufficient to stimulate demand and overcome deflation. The causes for the present situation are the weaknesses of mechanisms transmitting monetary policy impulses to the economy resulting from: 1) pessimistic expectations within Eurozone regarding economic growth, 2) lack among policy tools of any forward guidance for the desirable mid-term level of crucial real magnitudes, 3) lack of sufficient flexibility in the inflation target policy, 4) the weakness of the securities purchase programmes which exerted only a temporary effect on the ECB's balance sheet and monetary base.

Keywords: non-standard monetary policy measures, quantitative easing, inflation expectations.

\section{La politique monétaire de la Banque centrale européenne et la menace de la déflation dans l'Union européenne}

L'objectif de ce text est d'évaluer si la gamme de mesures non conventionnelles entreprises par la Banque centrale européenne entre 2014 et 2015 pourrait se révéler insuffisante pour stimuler la demande et surmonter la déflation. Les causes de la situation actuelle sont les faiblesses des mécanismes de transmission des impulsions de la politique monétaire à l'économie résultant: 1) des attentes pessimistes au sein de la zone euro en matière de croissance économique, 2) du manque parmi les outils de la politique de toutes indications prospectives pour le niveau souhaitable à moyen terme des grandeurs réelles cruciales, 3) du manque de flexibilité suffisante dans la politique de ciblage d'inflation, 4) de la faiblesse des programmes d'achat de titres qui avaient seulement un effet temporaire sur le bilan de la BCE et de la base monétaire.

Mots-clés: les mesures de politique monétaire non conventionnelles, l'assouplissement quantitatif, les attentes d'inflation. 


\section{Денежно-кредитная политика Европейского центрального банка и угроза дефляции в Европейском союзе}

Цель статьи заключается в рассмотрении, могут ли нестандартные меры, предпринимаемые Европейским центральным банком в 2014-2015 гг., оказаться недостаточными для того, чтобы стимулировать спрос и преодолеть дефляцию. Причиной сложившейся ситуации является слабость механизмов, передающих импульсы денежно-кредитной политики экономике, в результате: 1) пессимистических ожиданий в отношении стран еврозоны, касающихся их экономического роста; 2) отсутствия в политических инструментах указаний относительно требуемого в среднесрочной перспективе уровня показателей; 3) отсутствия достаточной гибкости в политике инфляционного таргетирования; 4) слабости программ покупки ценных бумаг, оказавших лишь временный эффект на баланс ЕЦБ и денежную базу.

Ключевые слова: нестандартные меры денежно-кредитной политики, количественное смягчение, инфляционные ожидания 